\title{
THE EFFECT OF SUBLETHAL CONCENTRATION OF DECIS 2.5 EC PESTICIDE ON LEARNING AND MEMORY PROCESSES IN COMMON CARP, CYPRINUS CARPIO (ACTINOPTERYGII: CYPRINIFORMES: CYPRINIDAE)
}

\author{
Robert DZIAMAN * , Marcin SITAREK, and Bernard KŁYSZEJKO \\ Division of Fish Physiology and Pathology, Faculty of Food Sciences and Fisheries, \\ West Pomeranian University of Technology
}

Dziaman R., Sitarek M., Kłyszejko B. 2010. The effect of sublethal concentration of Decis 2.5 EC pesticide on learning and memory processes in common carp, Cyprinus carpio (Actinopterygii: Cypriniformes: Cyprinidae). Acta Ichthyol. Piscat. 42 (2): 145-154.

\begin{abstract}
Background. Animals acquire new skills due to conditioned responses resulting from a sequence of neutral and unconditioned stimuli affecting their bodies; there is a constant time interval between the stimuli. Both stimuli become associated after a number of repetitions and animal bodies start to respond to the initially neutral stimulus as to the unconditioned one. The aim of this study was to determine whether exposure of fish to a pyrethroiddeltamethrin (an active ingredient in Decis 2.5 EC pesticide that disturbs the proper operation of the nervous system) affects the ability to learn in common carp.

Materials and Methods. Production of new types of behaviour was triggered in fish by using the unconditioned stimulus (an irritating electric impulse) and the conditioned stimulus (light). The experiment was performed in a tank divided into two compartments where fish could swim freely from one compartment to another. The ability to learn was assessed on the basis of the following types of behaviour evoked in response to the conditioned stimulus: locomotor agitation, preference to occupy or avoid certain areas in the tank, an escape response, etc. Results. In fish exposed to $0.35 \mu \mathrm{g} \cdot \mathrm{L}^{-1}$ deltamethrin (for common carp concentration 10 times lower than lethal) for $35 \mathrm{~min}$ the ability to produce and remember the conditioned defence response was reduced and time interval since presenting the conditioned stimulus till occurring the initial signs of the conditioned response was prolonged. Conclusion. The classical conditioning method revealed that sublethal concentration of deltamethrin restricted ability to learn and retain information in common carp, despite absence of observable intoxication symptoms.
\end{abstract}

Keywords: common carp, deltamethrin, learning and memory processes

\section{INTRODUCTION}

The ability to learn is one of the most important benefits gained from the evolution. Animals acquire new skills due to conditioned responses. A conditioned response is triggered by presentation of a neutral stimulus along with a stimulus of some significance. Once some sequences of both stimuli have been repeated, they become associated in the relevant encephalic centres and animal bodies start to respond to the initially neutral stimulus as to the unconditioned one. New types of animal behaviour produced in such a manner are known as 'classical conditioning'; when lower vertebrates are concerned the mentioned term is regarded as more relevant than 'learning' (Jackson et al. 1970).

In various experiments on learning abilities in fish performed with the use of the classical conditioning method, the most frequent unconditioned stimulus was an irritating electric impulse (6-25 V) induced for 0.2-1.0 s. Light, usually lasting for 10-20 s, was mainly used as the con- ditioned stimulus (Agranoff and Klinger 1964, Davis 1968, Jackson et al. 1970, Bintz 1971, Liu and Braud 1974, Scobie and Bliss 1974). Such experiments usually involved tanks divided into a few compartments between which where the fish could swim freely. The ability to learn was assessed on the basis of the following types of behaviour: locomotor agitation, preference to occupy or avoid certain areas in the tank, an escape response, etc. evoked in response to the conditioned stimulus (Davis 1968, Jackson et al. 1970, Bintz 1971, Liu and Braud 1974, Scobie and Bliss 1974, Kynard 1974, Giattina and Garton 1983, Tzschentke 1998, Darland and Dowlinng 2001, Craft et al. 2003).

The classical conditioning proved effective in determining the effect on fish of various chemical substances (ethanol, DDT), UV radiation, as well as feeding and defence behaviours (Jackson et al. 1970, Scobie and Bliss 1974, Scholz et al. 2000, Kelly and Bothwell 2002).

Pyrethroid insecticides constitute a numerous group among the plant pesticides running off to the aquatic

\footnotetext{
* Correspondence: Dr Robert Dziaman, Zakład Fizjologii i Patologii Ryb, Wydział Nauk o Żywności i Rybactwa, Zachodniopomorski Uniwersytet Technologiczny w Szczecinie, ul. Kazimierza Królewicza 4, 71-550 Szczecin, Poland, phone: (+48) 91 449 6621, fax: (+48) 91 449 6657, e-mail: rodziaman@zut.edu.pl
} 
ecosystem due to agricultural activities. Pyrethroids are used in the aquaculture to control some fish parasites such as Lepeophterius salmonis in salmon farming (Toovey and Lyndon 2000). What pyrethroid insecticides have in common is how they function: they inhibit in open position ion channels in the area of synaptic junctions what results in inhibiting conduction in the nervous system (Lund 1984).

Pyrethroids have a negative temperature coefficient. They show moderate toxicity to homeothermic animals and high toxicity to poikilothermic animals. Functional symptoms of intoxication are: boosted activity and sensitivity to external stimuli, then convulsions and paralysis (Staatz et al. 1982).

Both high and low concentrations of pyrethroids are harmful to fish. High concentration disturbs directly neural conduction while low concentration leads to changes in the enzymatic and hormonal activity (Szegletes et al. 1995, Svobodová et al. 2003, Velíšek et al. 2006) and also leads to disturbing ionic balance and osmoregulation (Bálint et al. 1995, Kłyszejko and Łyczywek 1999) as well as the anatomic and pathologic changes in the internal organs (Kumaraguru et al. 1982).

Deltamethrin (an active substance in the agent of trade name Decis $2.5 \mathrm{EC}$ ) is one of pyrethroid insecticides widely used in agriculture, growing fruits, vegetables, decorative plants, and forestry for control of chewing and siphoning insects.

Deltamethrin radically affects neurotransmitters (inhibits acetylcholinesterase activity) in the central and peripheral nervous system (Abbassy et al. 1983, Csilik et al. 2000).

The half-life period of deltamethrin in the aquatic environment is 4-8 days (Łakota et al. 1990, Szerow et al. 1996), and concentration lethal to common carp fry determined according to $\mathrm{LC}_{50}$ criterion is $3.5 \mu \mathrm{g} \cdot \mathrm{L}^{-1}$ (Lakota 1992). In common carp exposed to low concentration of deltamethrin $\left(0.14 \mu \mathrm{g} \cdot \mathrm{L}^{-1}\right)$ for $24 \mathrm{~h}$ statistically significant fluctuations were observed in the levels of: glucose, chloride, sodium and potassium ions, total calcium, creatinine, urea nitrogen, and cholesterol in the blood serum (Kłyszejko and Łyczywek 1999). When exposed to deltamethrin for a longer time (34-60 days), carp are affected by significantly lower concentrations $\left(0.01-0.1 \mu \mathrm{g} \cdot \mathrm{L}^{-1}\right)$ showing increased activity of enzymes involved in detoxification in the liver (Przybylska-Wojtyszyn et al. 1992).

Moreover, deltamethrin was used in mosquito-killing campaigns what resulted in mass mortality of eel in Lake Balaton in 1991 and 1995. In the dying eels, blood serum acetylcholinesterase activity was significantly inhibited, blood glucose content was $2.5 \times$ higher and deltamethrin concentrations in the fish brains and livers were high (Bálint et al. 1997).

The aim of this study was to determine whether exposure of common carp, Cyprinus carpio L., to a poison, that disturbs the proper operation of the nervous system, affects the conditioning ('learning') process in the fish. Using the classical conditioning method, we examined the ability to produce and retain conditioned response in common carp exposed to lethal concentration of deltamethrin for a short time.

\section{MATERIAL AND METHODS}

The study was conducted in the autumn and involved a total of 100 individuals of common carp, Cyprinus carpio L., each weighing 100-200 g. The fish were provided by the cage farm situated on the warm-water discharge canal of the 'Dolna Odra' power station near Szczecin, in five successive batches of 20 fish each, in two-week intervals. Prior to the experiment, the fish from each batch were acclimated to the laboratory conditions for 14 days in a 1000-L tank, at temperature $18 \pm 1^{\circ} \mathrm{C}, \mathrm{pH} 7.4-8.2$, and oxygen content $8.2-10.4 \mu \mathrm{g} \cdot \mathrm{L}^{-1}$. The fish from each batch were divided to a control and experimental groups consisting of 10 fish each. This way we had a total of 50 control fish and 50 experimental fish. Each experiment was performed on one fish at a time. The fish of the experimental group were exposed to $0.35 \mu \mathrm{g} \cdot \mathrm{L}^{-1}$ deltamethrin. The source of deltamethrin was insecticide Decis 2.5 manufactured by Horst Schering (Germany). Firstly, the fish were intoxicated for $35 \mathrm{~min}$ in 20 -L tank containing solution of insecticide, then they were moved to the experimental tank with pure and saturated water. The control fish were treated in the same manner except for exposure to the pyrethroid.

The experimental tank was separated into two compartments of the same size by a non-transparent barrier. In each compartment, there were two copper plates connected to the electric impulse generator (a source of the irritating 'unconditioned' stimuli) and a bulb (a source of 'neutral' stimuli) situated over the water surface. There was a hole in the lower part of the barrier at the tank bottom, enabling fish to swim freely from one compartment to another. The upper part of the barrier was jutting out of water thus it became a screen. The screen enabled each bulb to shine only over the compartment they were located (Fig. 1).

The aquarium walls were covered with foamed polystyrene to restrict access of undesirable external stimuli (mainly light and acoustic ones) to fish. The control system enabled to perform the conditioning process in both compartments independently of each other. The conditioning process, described below, started in both (control and experimental) groups after a $24-\mathrm{h}$ presence in the experimental aquarium.

The following stimuli were used to produce the conditioned response:

Unconditioned stimulus: a $9 \mathrm{~V}$ square electric impulse with voltage of $100 \mathrm{~mA}$ emitted for $1 \mathrm{~s}$. The emitter of impulses was a P-364 feeder, manufactured by ELPO in Wrocław, connected to the plates situated in the compartments of the experimental tank;

Conditioned stimulus: a ray of orange light emitted by a $60 \mathrm{~W}$ bulb for $12 \mathrm{~s}$. Orange light was used to make a stimulus more sharp as there was some white light in the laboratory necessary to observe fish behaviour during the experiments.

A precise control over the stimuli was obtained by using a time programmer NE 2053 from Nord Elektronik and an electronic control system made by the Apparatus Repair Workshop of the Agricultural University of Szczecin.

Procedure. To produce the conditioned response, an orange bulb was turned on for $12 \mathrm{~s}$ over the compartment 
with a fish present, and in the last second of the light stimulus a $1 \mathrm{~s}$ irritating electric stimulus was turned on. The stimuli sequence was provided in 2 min intervals and each fish undergone 20 repetitions. The behaviour of fish was

\section{RESULTS}

The experiments performed on fish revealed that the course of the unconditioned response in all the fish was exactly the same: the electric stimulus evoked body twitch as well

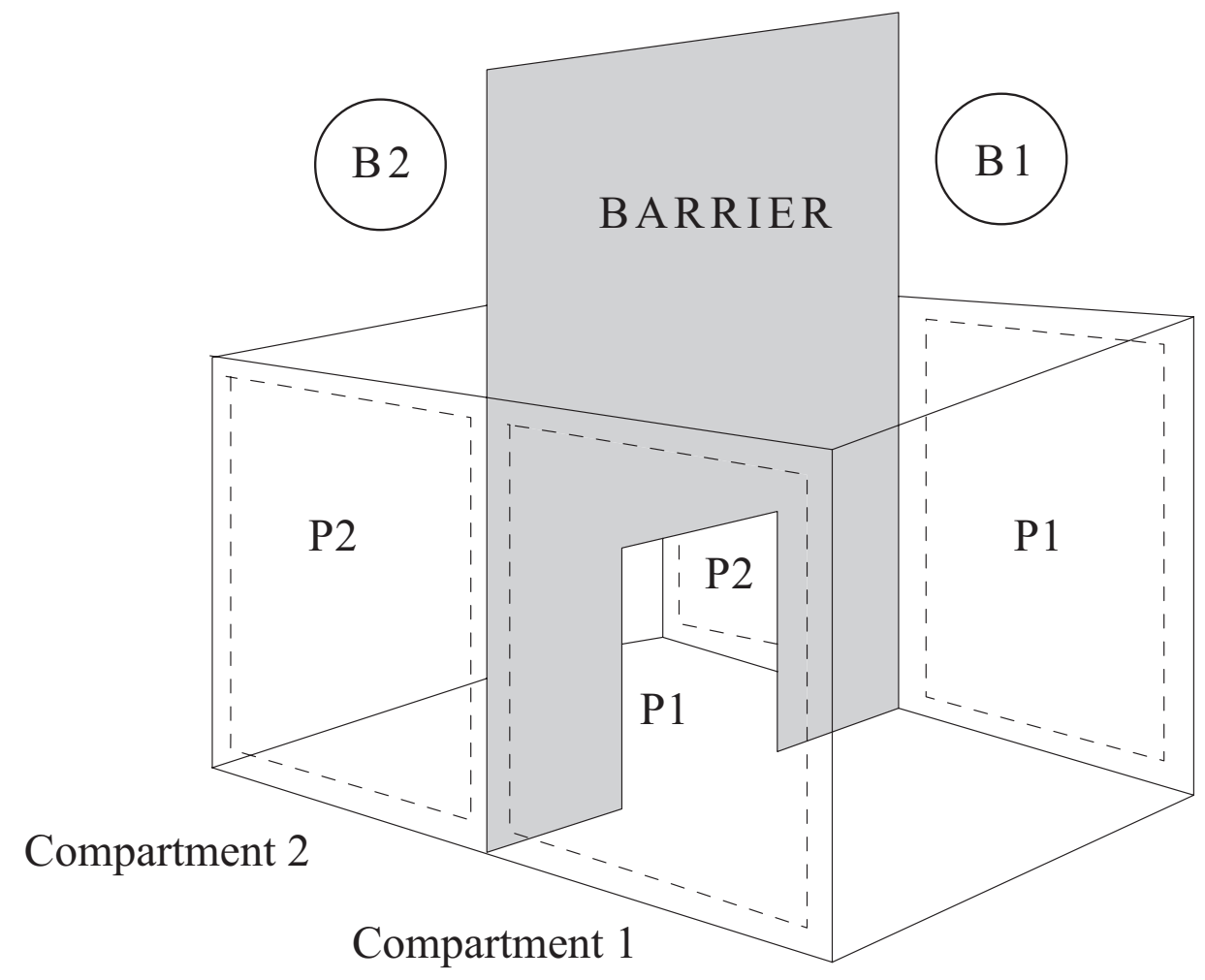

Fig. 1. Experimental tank: B1, B2 = bulbs (sources of the conditioned stimulus), P1, P2 = plates, their surface is shown by a broken line

observed; once responses considered as conditioned have occurred, the time between producing the conditioned stimulus and occurring the response was measured. Following responses were regarded as conditioned:

Weak response: weak locomotor agitation, nondirectional chaotic fish motion;

Strong response: strong locomotor agitation, restlessness, fish motion shows directional symptoms: they avoided the vicinity of plates, occupied or swam toward the barrier separating the tank compartments;

Escape response: directional motion: when light stimulus occurred fish moved to the neighbouring compartment, that was safe at that moment, to avoid irritating action of the electric impulse.

Fish behaviour evoked by the electric stimulus only as well as types of behaviour during 2 min intervals between the consecutive stimuli sequences was not included in the assessment of the conditioning.

In both groups of fish (control and experimental) producing the conditioned response to light was described as 1st conditioning while testing a life of acquired response (performed $24 \mathrm{~h}$ later) was described as $\mathbf{2 n d}$ conditioning.

The results of this study were processed statistically applying the Wilcoxon signed-rank test using the Statistica ${ }^{\circledR} 6.0$ and MS Excel ${ }^{\circledR} 2000$ software. as sudden and chaotic locomotor movements lasting for 1-2 s.

As to the response to the light stimulus, some differences occurred, and depending on the intensity of reactions, the conditioned responses were divided into weak responses, strong responses and escape response.

During the 1st conditioning (Fig. 2), the first conditioned responses in the control group occurred in $19 \%$ of fish after 4 repetitions of the stimuli sequence, and all the fish started to respond to the light stimulus after 9 repetitions. In the group previously exposed to deltamethrin, the initial sign of the conditioned response occurred in $4 \%$ of fish after 5 repetitions and in all the fish after 12 repetitions of the stimuli sequence.

Testing the life of the produced response after $24 \mathrm{~h}$ (2nd conditioning) has shown that all the fish of the control group retained the stimulus (Fig. 3). In the group of fish exposed to deltamethrin, the conditioned response has been retained by $46 \%$ of fish under experiment and the response for all fish has been re-produced after additional 11 repetitions of the stimuli sequence.

Analysis of the control fish responses to the light stimulus revealed that the number of weak and strong responses was decreasing while a number of escape responses was increasing during the conditioning. Percentage share of these types of behaviour in the control group after 20 repetitions was: $7 \%, 41 \%$, and $52 \%$, respec- 
tively (Fig. 4: 1st conditioning) and after $24 \mathrm{~h}$ (Fig. 5: 2nd conditioning): $7 \%, 14 \%$, and $79 \%$, respectively.

The course of the 1st conditioning in fish previously exposed to deltamethrin (Fig. 6), revealed that starting with the 11th stimuli sequence (when the conditioned response was produced in the entire group), the frequency of escape response increased and a number of strong responses decreased, and at the end of the experiment (20th repetition of the stimuli sequence) weak locomotor agitation was observed in 44\%, strong locomotor agitation - in 20\%, and escape response - in 36\% of fish.
After $24 \mathrm{~h}$ (2nd conditioning) weak responses were observed in $24 \%$, strong responses - in 30\%, and escape response - in $46 \%$ of fish exposed to deltamethrin (Fig. 7). At the end of the experiment (20th stimuli sequence) the occurrence of strong responses increased to $36 \%$, a number of weak responses decreased to $18 \%$, while a number of behaviour concerned as escape response remained at the same level.

Response time. For the purpose of this article the term response time is time interval between the moment of producing the light stimulus and occurring the initial signs of the conditioned response.

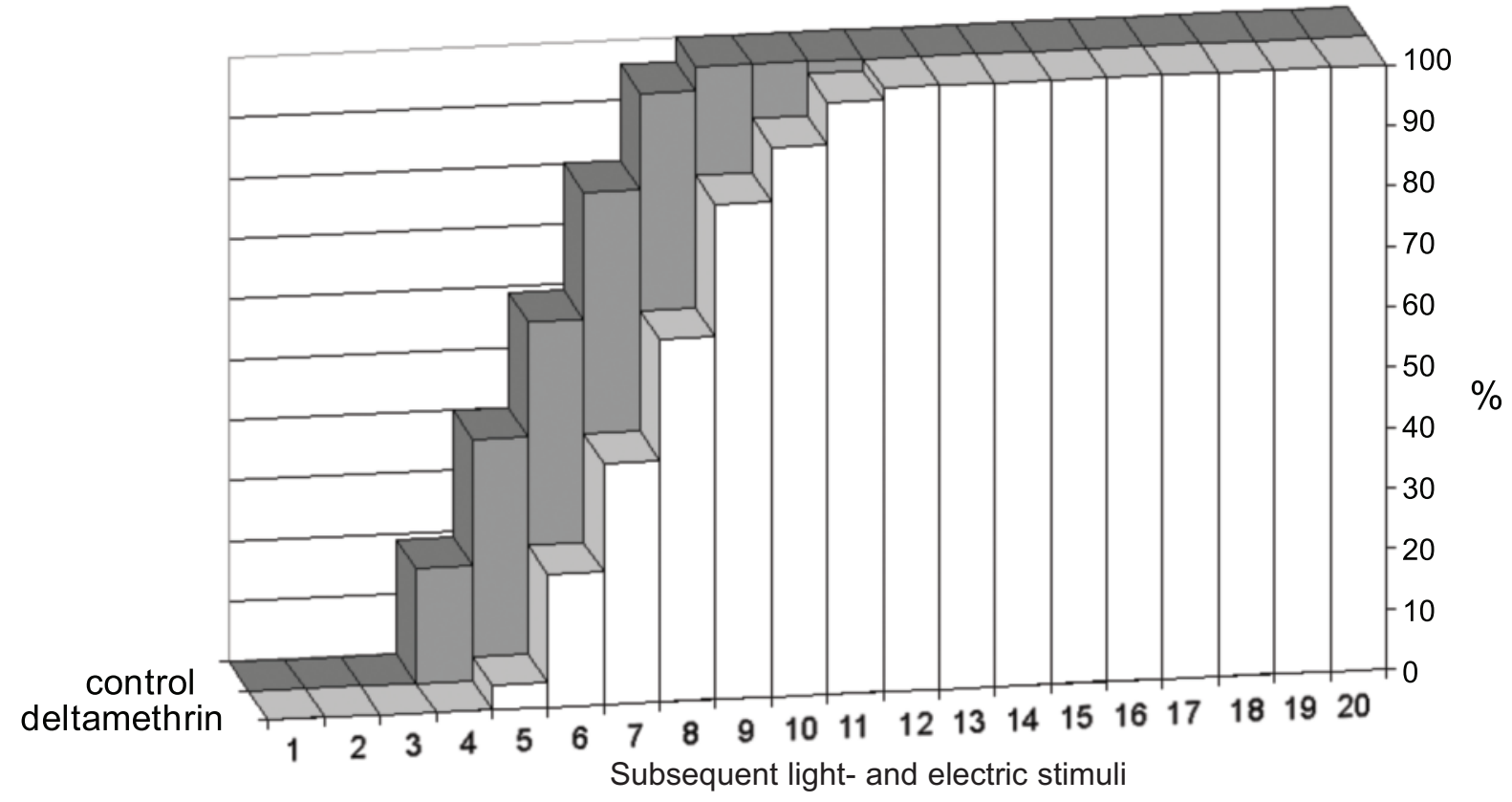

Fig. 2. Progress of conditioning process (1st conditioning) in common carp of the control group and of the group exposed to deltamethrin

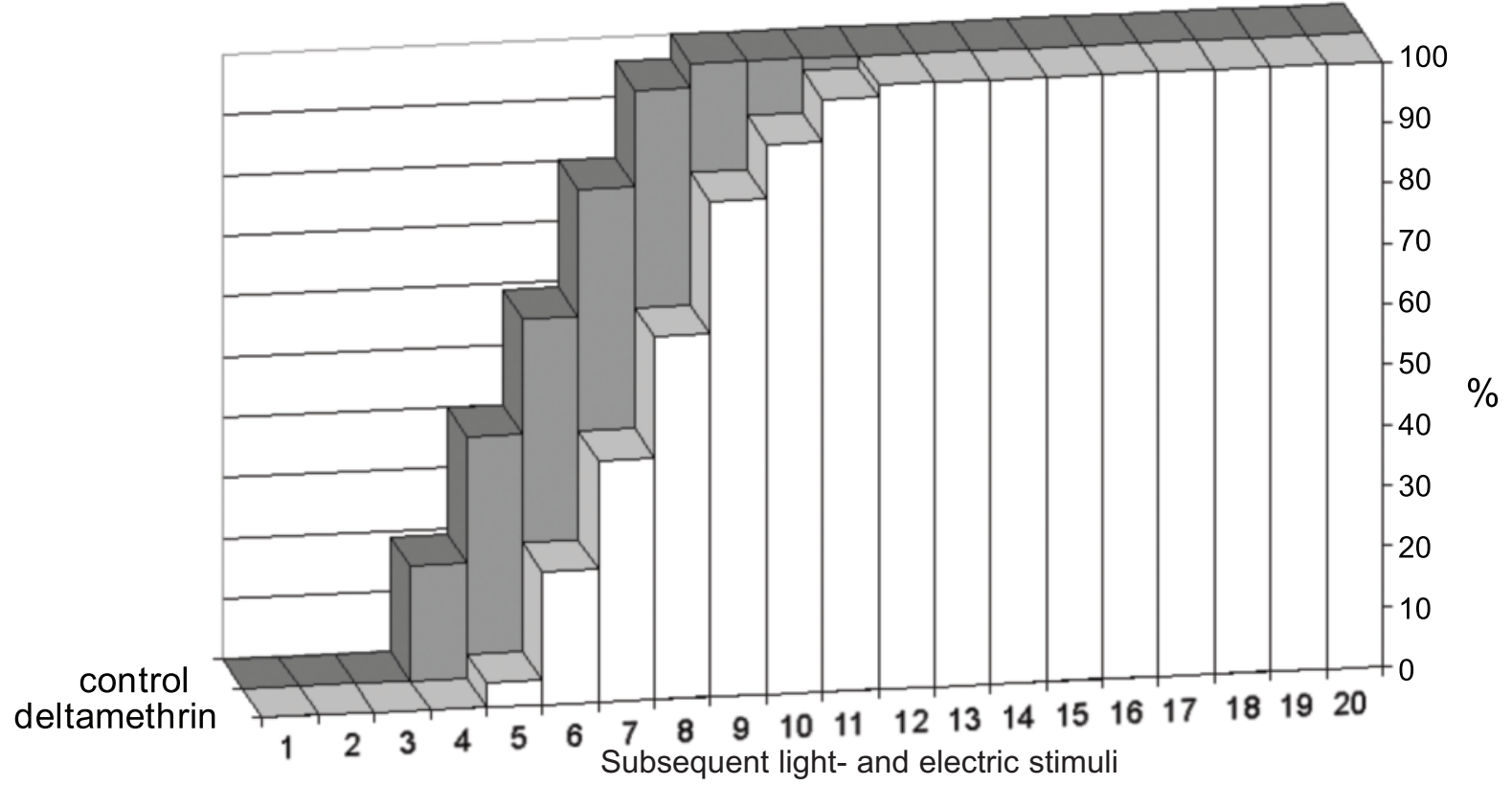

Fig. 3. Durability/Persistence of the conditioned response (2nd conditioning) recorded after $24 \mathrm{~h}$ in common carp of the control group and of the group exposed to deltamethrin 


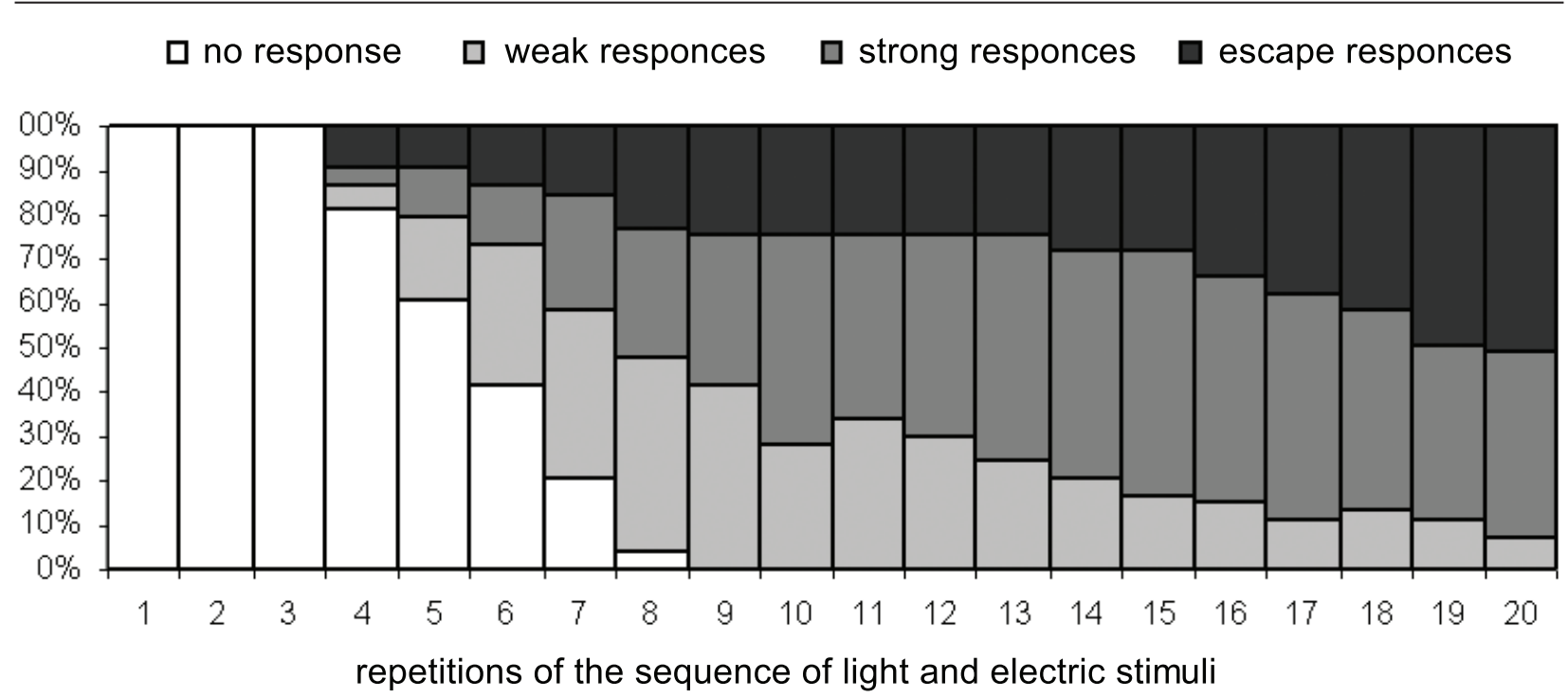

Fig. 4. Percentage share/distribution of conditioned response in common carp; Control group, 1st conditioning

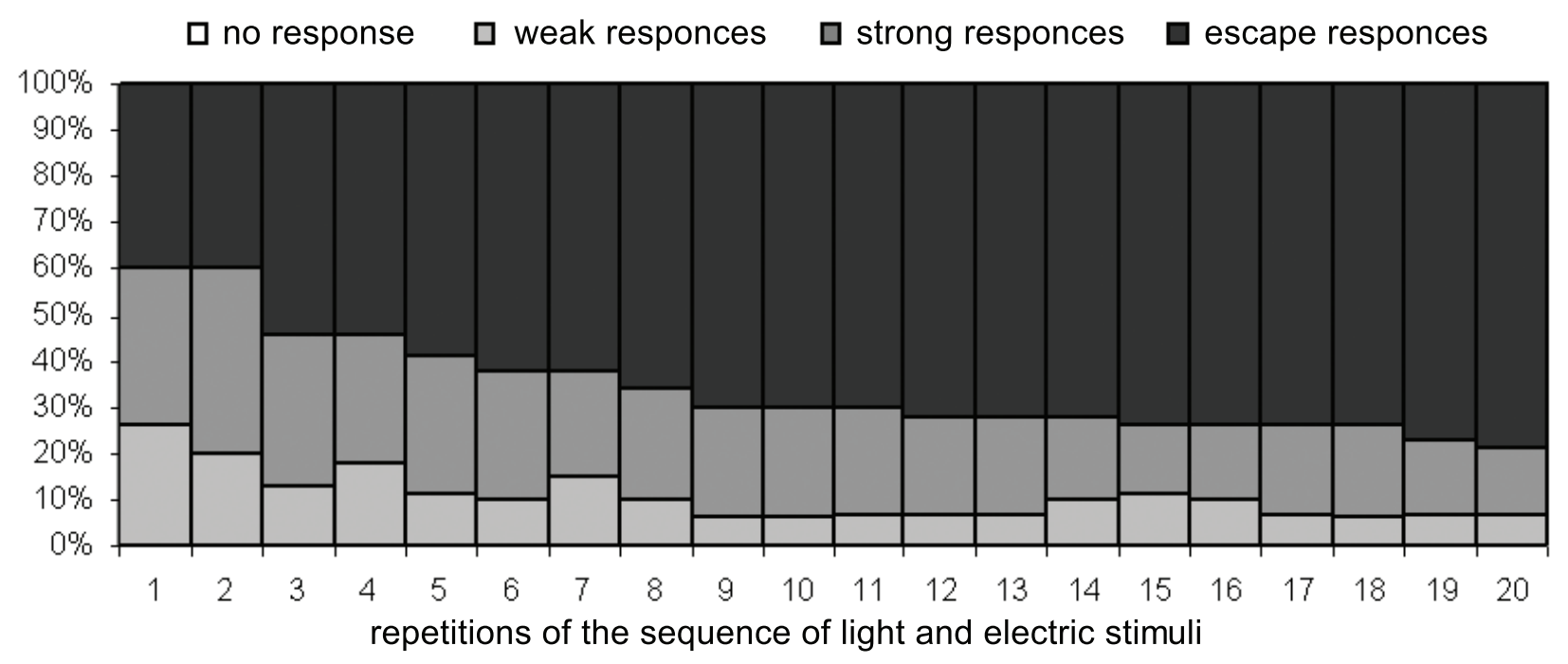

Fig. 5. Percentage share/distribution of conditioned response in common carp: Control group, 2nd conditioning

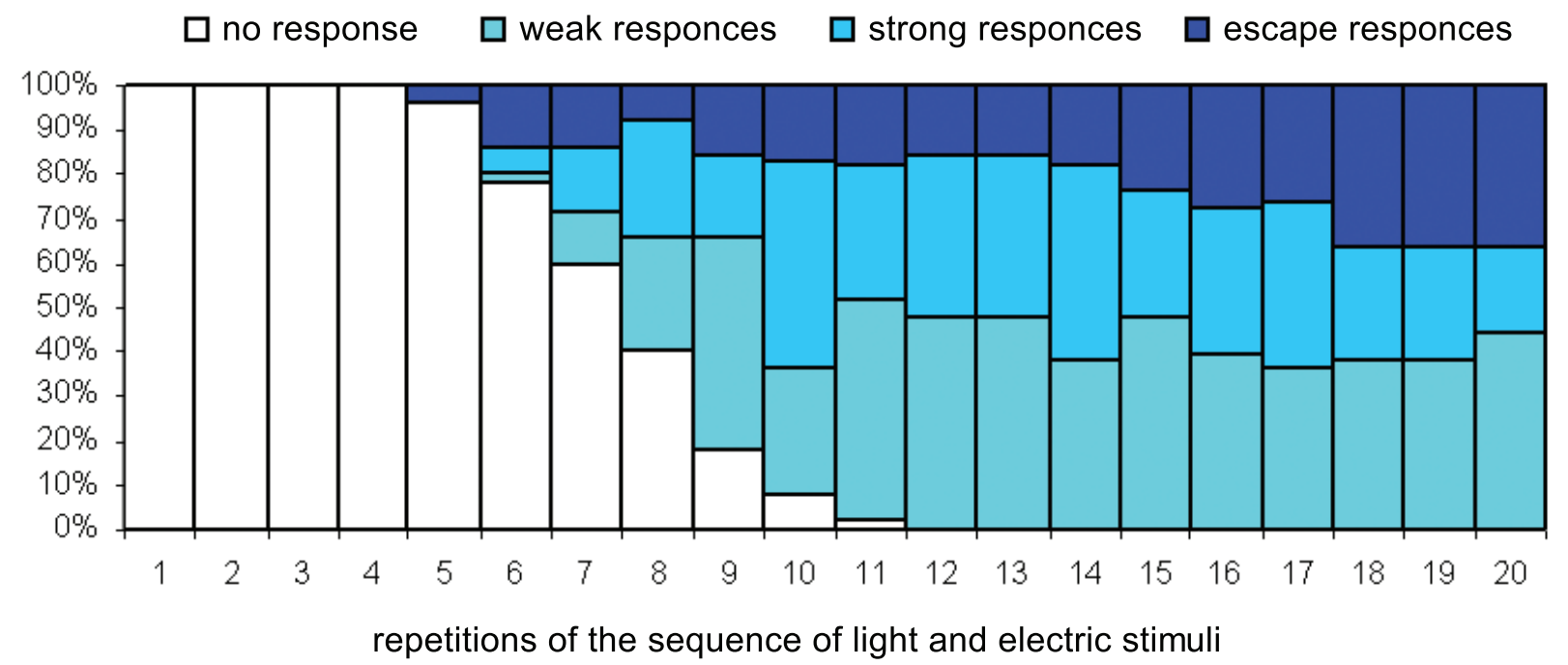

Fig. 6. Percentage share/distribution of conditioned response in common carp exposed to deltamethrin; 1 st conditioning 
The results revealed that in the control group during the first conditioning (Fig. 8), response time at the beginning of the experiment was $6.6 \mathrm{~s}$ on average, while at the end (20th repetition of the stimuli sequence) it decreased to $1.4 \mathrm{~s}$. During the second conditioning further decrease in response time was observed (first stimuli sequence- $5.2 \mathrm{~s}$; 20 th repetition-1.2 $\mathrm{s}$ ).

In fish exposed to deltamethrin, during the 1 st conditioning the average response time at the beginning of the experiment (5th repetition of stimuli sequence) was $5.5 \mathrm{~s}$, while at the end of the experiment it decreased to $1.8 \mathrm{~s}$ (Fig. 8).
During the second conditioning, at the beginning of the experiment the response time was $5 \mathrm{~s}$ (first stimuli sequence) but in the 20th repetition it decreased to $2.6 \mathrm{~s}$.

\section{DISCUSSION}

This study was focused on deltamethrin influence on the memory processes in fish. Using the classical conditioning method it was proved that short-term (35 min) exposure of common carp to this pyrethroid (in concentration 10 times lower than lethal) reduced its ability to learn and retain responses.

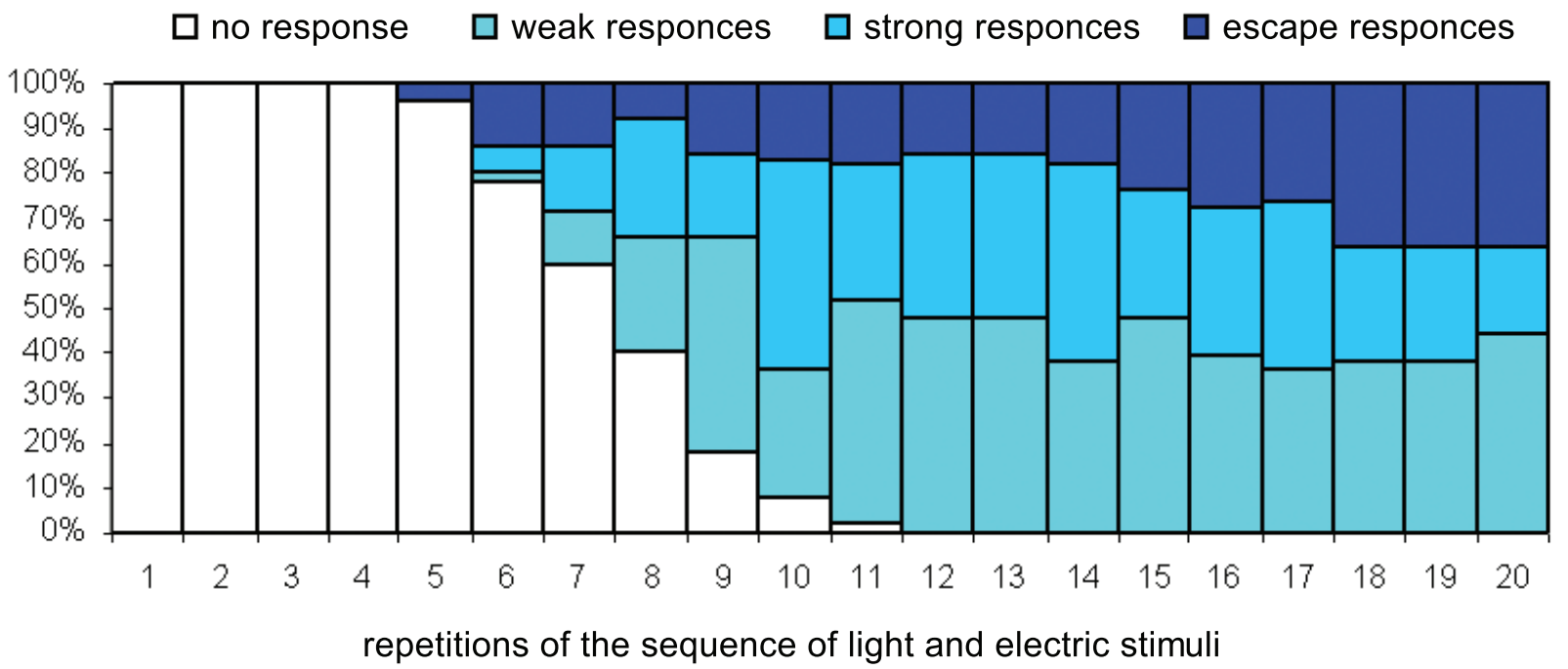

Fig. 7. Percentage share/distribution of conditioned response in common carp exposed to deltamethrin; 2nd conditioning Subsequent light and electric stimuli.

- - Control group, 1st conditioning

- Deltamethrin, 1st conditioning
- Control group, 2nd conditioning

- Deltamethrin, 2nd conditioning

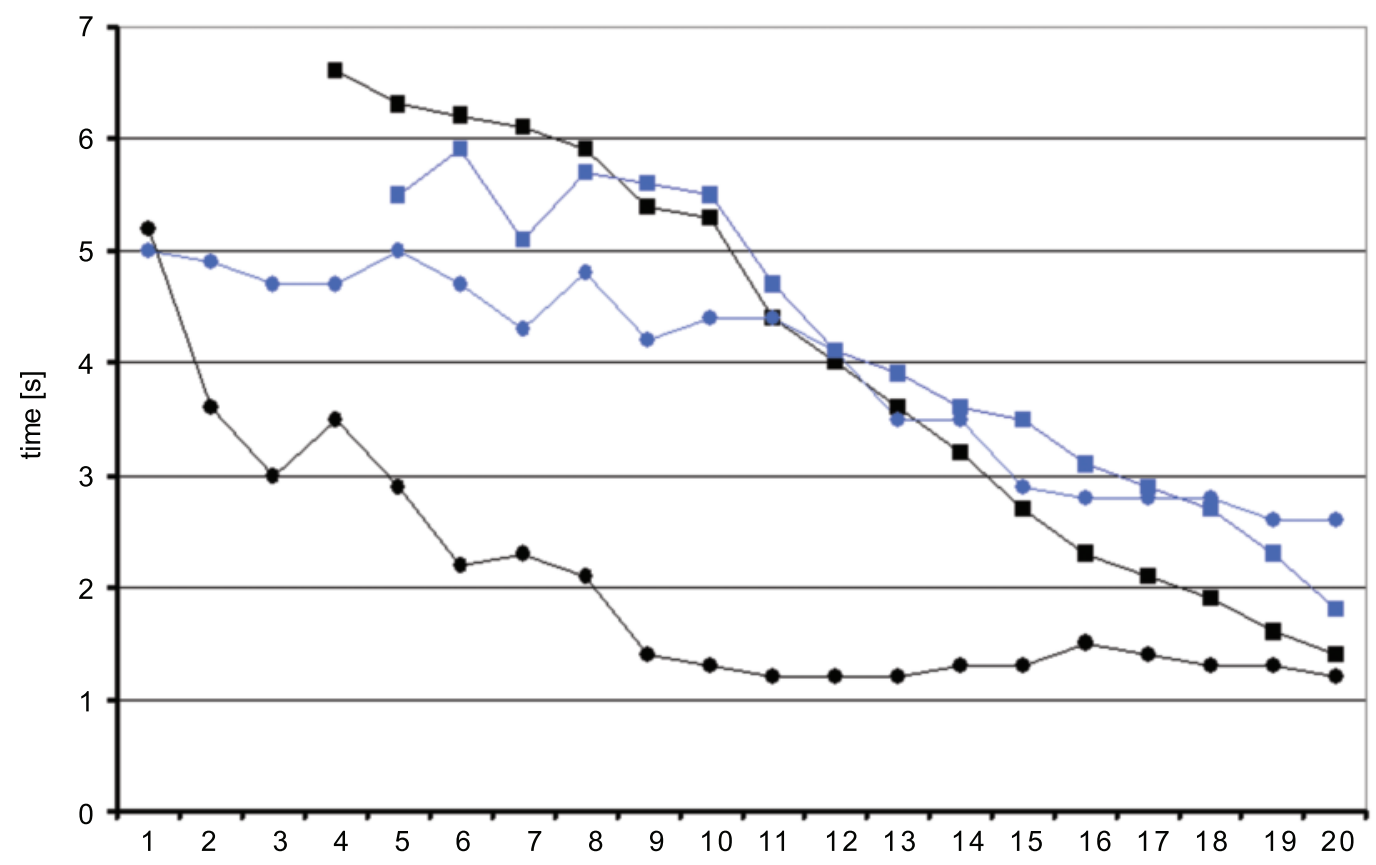

Fig. 8. Response time in common carp of the control group and of the group exposed to deltamethrin 
Production of the conditioned response was performed in 20 repetitions of stimuli sequences (1st conditioning) and the experiments were repeated after $24 \mathrm{~h}$ (2nd conditioning) to determine the life of produced responses. The interval between learning and testing types of behaviour was in compliance with the procedure for studies performed with the use of the classical conditioning in lower vertebrates and invertebrates (Agranoff et al. 1965, Davis and Agranoff 1966, McGaugh 1966, Liu and Braud 1974, Sutton et al. 2002).

During the 1 st conditioning, the fish previously exposed to deltamethrin (Fig. 2) required more repetitions of the stimuli sequences to produce the conditioned response, comparing to the control group.

The 2 nd conditioning (testing the life of the produced response) revealed that all the fish of the control group responded to the light stimulus already in the first stimuli sequence, while the fish exposed to pesticide had decreased ability to retain responses (Fig. 3). Similar weakening of long-term memory was observed by Agranoff and Klinger (1964) and Davis and Agranoff (1966) in crucian carp previously exposed to puromycin (a drug inhibiting replication of viral nucleic acids and protein synthesis).

Comparing with the higher vertebrates, behavioural responses in fish are poor in variety and most of their responses to stimuli are not specific; they mainly respond through changes in locomotor activity, breathing frequency, various levels of restlessness, balance disturbances, etc. (Giattina and Garton 1983, Tzschentke 1998).

Fish behavioural responses also include 'avoidance' or 'preference' responses that are mainly used for studying repelling or luring activity of chemical substances. Avoiding or preferring is related to the place where a certain substance has been dissolved.

Experiments using the classical conditioning method are usually performed in tanks separated into compartments, where the equivalent of the 'avoidance' response is an escape response i.e. going to the neighbouring compartment to avoid negative stimulus. Most scientists regard 'escape' as the most objective symptom of the learning process (Agranoff et al. 1965, Agranoff and Klinger 1966, Anderson and Peterson 1969, Davis 1968, Jackson et al. 1970, Bintz 1971, Riege and Cherkin 1973, Scobie and Bliss 1974, Giattina and Garton 1983).

For the purpose of this article, the types of fish behaviour during conditioning were divided into the following responses: 'weak' (stimulation and chaotic locomotor movements), 'strong' (movements more and more directional, avoiding the vicinity of the plates) and the most beneficial type of behaviour such as 'escape' to the neighbouring compartment in the tank. On the basis of the experiments we observed that once a fish had managed to avoid the electric stimulus, it always responded with escape until the end of the experiment. This may indicate that in common carp it was not only association between the two various stimuli but also between the type of behaviour and its result.
During 2nd conditioning, the escape response occurred at the end of the experiment in $80 \%$ of fish in the control group (Fig. 5), while deltamethrin has decreased the frequency of such a response occurrence (Fig. 7). According to the available literature, similar decrease in the ability of fish to avoid irritating electric impulse was observed in salmon previously exposed to DDT (Anderson and Peterson 1969).

Time between producing stimulus to occurring response is called 'response time' or 'time of response latency' and its shortening, particularly in avoidance responses, is beneficial to the organism. Experiments described in this article demonstrated that response time during the 1st conditioning in the control group has decreased four times and its further decrease occurred during the 2nd conditioning. In the fish exposed to deltamethrin a decrease in response time was also observed, however, it was slower than in the control group (Fig. 8). It seems that one of the reasons could be inhibiting synaptic conduction by the pyrethroid what was proved by numerous studies (Deutsch 1971, D’Mello 1993, Pan and Dutta 1998, Csilik et al. 2000).

The scientific reports of the recent years confirm that the learning and memory processes depend on the activity of neurotransmitters in the brain structures. While shortterm memory is concerned, there is a temporary increase in sensitivity of synapses to neurotransmitter and in longterm memory - sensitivity of synapses to the consecutive stimulation is constant in character (Deutsch 1971, Mamounas et al. 1987, Tronel et al. 2004).

Molecular mechanisms involved in the memory process have not been recognized in details yet. The scientists share the opinion that retaining acquired information or type of behaviour (e.g., conditioned response), then moving it from short-term to long-term memory results from creating specific proteins that permanently accelerate synaptic transmission. Factors involved in the expression of genes responsible for the synthesis of these proteins are currently under intensive examination (Fields et al. 1990, Ginty et al. 1993, Worley et al. 1993, Xia et al. 1996, Ai et al. 1998, Levenson et al. 2004, Alberini 2005, Ko et al. 2005).

Numerous experiments proved that inhibiting DNA transcription into mRNA, as well as mRNA translation in protein, prevents from creating long-term paths in memory (Bailey et al. 1996, Fields et al. 1997, Igaz et al. 2002, Sutton et al. 2004, Alberini 2005). Toxins such as diazinon - an active substance in organophosphate pesticide (Marinovich et al. 1996) and pyrethroids (Imamura et al. 2000)-were observed to inhibit gene transcription enabling creating 'memory' proteins.

Comparing with the detailed analysis at the molecular level, experiments performed in this study are rather an attempt to a 'holistic' assessment of effects of a substance disturbing the function of the nervous system in fish. It was shown with the use of the classical conditioning method that sublethal concentration of deltamethrin (an active substance in Decis 2.5 EC pesticide) hinders acquiring and retaining information in common carp. 
Restricted ability to learn and retain information decreases opportunity for animals to adjust to the changes in the environment. This study has demonstrated that presence of neurotoxins from plant pesticides in water may be the reason for such a dysfunction in fish.

\section{REFERENCES}

Abbassy M.A., Eldefrawi M.E., Eldefrawi A.T. 1983. Influence of the alcohol moiety of pyrethroids on their interactions with the nicotinic acetylcholine receptor. Journal of Toxicology and Environmental Health A 12 (4-6): 575-590. DOI: 10.1080/15287398309530450.

Agranoff B.W., Davis R.E., Brink J.J. 1965. Memory fixation in the goldfish. Proceedings of the National Academy of Sciences of the United States of America 54 (3): 788-793.

Agranoff B.W., Klinger P.D. 1964. Puromycin effect on memory fixation in the goldfish. Science 146 (3646): 952-953. DOI: $10.1126 /$ science.146.3646.952.

Ai X., MacPhedran S.E., Hall A.K. 1998. Depolarization stimulates initial calcitonin gene- related peptide expression by embryonic sensory neurons in vitro. The Journal of Neuroscience 18 (22): 9294-9302.

Alberini C.M. 2005. Mechanisms of memory stabilization: are consolidation and reconsolidation similar or distinct processes? Trends in Neurosciences 28 (1): 51-56. DOI: 10.1016/j.tins.2004.11.001.

Anderson J.M., Petersont M.R. 1969. DDT: sublethal effects of brook trout nervous system. Science 164 (3878): 440-441. DOI: 10.1126/science.164.3878.440

Bailey C.H., Bartsch D., Kandel E.R. 1996. Toward a molecular definition of long-term memory storage. Proceedings of the National Academy of Sciences of the United States of America 93 (24): 13445-13252.

Bálint T., Ferencsy J., Kátai J., Kiss I., Kráczer L., Kufcsák O., Láng G., Polyhos C., Szabó I., Szegletes T., Nemcsók J. 1997. Similarities and differences between the massive eel (Anguilla anguilla L.) devastations that occurred in Lake Balaton in 1991 and 1995. Ecotoxicology and Environmental Safety 37 (1): 17-23. DOI: 10.1006/eesa.1996.1509.

Bálint T., Szegletes T., Szegletes Zs., Halasy K., Nemcsók J. 1995. Biochemical and subcellular changes in carp exposed to the organophosphorus methidathion and the pyrethroid deltamethrin. Aquatic Toxicology 33 (3-4): 279-295. DOI: $10.1016 / 0166-445 X(95) 00029-4$.

Bintz J. 1971. Between- and within-subject effect of shock intensity on avoidance in goldfish (Carassius aureatus). The Journal of Comparative and Physiological Psychology 75: (1): 92-97.

Craft B.E., Velkey A.J.II, Szalda-Petree A. 2003. Instrumental conditioning of choice behavior in male Siamese fighting fish (Betta splendens). Behavioural Processes 63 (3): 171-175. DOI: 10.1016/S0376-6357(03)00079-2.

Csillik B., Fazakas J., Nemcsók J., Knyihár-Csillik E. 2000. Effect of pesticide deltamethrin on the mauthner cells of the Lake Balaton fish. Neurotoxicology 21 (3): 343-352.

Darland T., Dowling J.E. 2001. Behavioral screening for cocaine sensitivity in mutagenized zebrafish. Proceedings of the National Academy of Sciences of Sciences of the United
States of America 98 (20): 11691-11696.

DOI: $10.1073 /$ pnas.191380698.

Davis R.E. 1968. Environmental control of memory fixation in goldfish. Journal of Comparative and Physiological Psychology 65 (1): 72-78. DOI: 10.1037/h0025398.

Davis R.E., Agranoff B.W. 1966. Stages of memory formation in goldfish: evidence for an environmental trigger. Proceedings of the National Academy of Sciences of the United States of America 55 (3): 555-559.

Deutsch A.J. 1971. The cholinergic synapse and the site of memory. Science 174 (4011): 788-794. DOI: $10.1126 /$ science. 174.4011 .788 .

D'Mello G.D. 1993. Behavioural toxicity of anticholinesterases in humans and animals - a review. Human and Experimental Toxicology 12 (1): 3-7. DOI: 10.1177/096032719301200101.

Fields R.D., Eshete F., Stevens B., Itoh K. 1997. Action potential-dependent regulation of gene expression: temporal specificity in $\mathrm{Ca}^{2+}$, cAMP-responsive element binding proteins, and mitogen-activated protein kinase signaling. The Journal of Neuroscience 17 (19): 7252-7266.

Fields R.D., Neale E.A., Nelson P.G. 1990. Effects of patterned electrical activity on neurite outgrowth from mouse sensory neurons. The Journal of Neuroscience 10 (9): 2950-2964.

Giattina J.D., Garton R.R. 1983. A review of the preferenceavoidance responses of fishes to aquatic contaminants. Residue Reviews 87: 43-90.

Ginty D.D., Kornhauser J.M., Thompson M.A., Bading H., Mayo K.E., Takahashi J.S., Greenberg M.E. 1993. Regulation of CREB phosphorylation in the suprachiasmatic nucleus by light and a circadian clock. Science 260 (5105): 238-241. DOI: 10.1126/science.8097062.

Igaz L.M., Vianna M.R.M., Medina J.H., Izquierdo I. 2002. Two time periods of hippocampal mRNA synthesis are required for memory consolidation of fear-motivated learning. The Journal of Neuroscience 22 (15): 6781-6789.

Imamura L., Hasegawa H., Kurashina K., Hamanishi A., Tabuchi A., Tsuda M. 2000. Repression of activity-dependent c-fos and brain-derived neurotrophic factor mRNA expression by pyrethroid insecticides accompanying a decrease in $\mathrm{Ca}^{2+}$ influx into neurons. The Journal of Pharmacology and Experimental Therapeutics 295 (3): 1175-1182.

Jackson D.A., Anderson J.M., Gardner D.R. 1970. Further investigations of the effect of DDT on learning in fish. Canadian Journal of Zoology 48 (3): 577-580. DOI: 10.1139/z70-096.

Kelly D.J., Bothwell M.L. 2002. Avoidance of solar ultraviolet radiation by juvenile coho salmon (Oncorhynchus kisutch). Canadian Journal of Fisheries and Aquatic Sciences, 59 (3): 474-482. DOI: 10.1139/f02-023.

Kłyszejko B., Lyczywek G. 1999. Effect of a sublethal concentration of deltametrin on biochemical parameters of the blood serum of carp (Cyprinus carpio L.). Acta Ichthyologica et Piscatoria 29 (2): 109-117.

Ko S., Zhao M.G., Toyoda H., Qiu C.S., Zhuo M. 2005. Altered behavioral responses to noxious stimuli and fear in glutamate receptor 5 (GluR5)-or GluR6-deficient mice. The Journal of Neuroscience 25 (4): 977-984. DOI: 10.1523/JNEUROSCI.4059-04.2005. 
Kumaraguru A.K., Beamish F.W.H., Ferguson H.W. 1982. Direct and circulatory paths of Permethrin (NRDC-143) causing histopathological changes in the gills of rainbow trout, Salmo gairdneri Richardson. Journal of Fish Biology 20 (1): 87-91. DOI: 10.1111/j.1095-8649.1982.tb03897.x.

Kynard B. 1974. Avoidance behavior of insecticide susceptible and resistant populations of mosquitofish to four insecticides. Transactions of the American Fisheries Society 103 (3): 557-561. DOI: 10.1577/1548-8659(1974)103<557:ABOISA>2.0.CO;2.

Levenson J.M., Choi S., Lee S.-Y., Cao Y.A., Ahn H.J., Worley K.C., Pizzi M., Liou H.C., Sweatt J.D. 2004. A bioinformatics analysis of memory consolidation reveals involvement of the transcription factor c-Rel. The Journal of Neurosciences 24 (16): 3933-3943.

DOI: $10.1523 /$ JNEUROSCI.5646-03.2004.

Liu Y., Braud W.G. 1974. Modification of learning and memory in goldfish trough the use of stimulant and depressant drugs. Psychopharmacologia 35 (2): 99-112. DOI: $10.1007 / \mathrm{BF} 00429577$.

Lund A.E. 1984. Pyrethroid modification of sodium channel: current concepts. Pesticide Biochemistry and Physiology 22 (2): 161-168. DOI: 10.1016/0048-3575(84)90085-3.

Lakota S., Kołodziejczyk E., Reszka A. 1990. Badania nad ubocznym działaniem pyretroidów na środowisko wodne. [Investigations on the side-effects of pyrethroids on the aquatic environment.] Pestycydy 4: 19-25. [In Polish.]

Mamounas L.A., Thompson R.F., Madden J.IV 1987. Cerebellar GABAergic processes: evidence for critical involvement in a form of simple associative learning in the rabbit. Proceedings of the National Academy of Sciences of the United States of America 84 (7): 2101-2105.

Marinovich M., Gilardi F., Galli C.L. 1996. Effects of pesticide mixtures on in vitro nervous cell: comparison with single pesticides. Toxicology 108 (3): 201-206. DOI: $10.1016 / 0300-483 X(96) 03303-3$.

McGaugh J.L. 1966. Time-dependent processes in memory storage. Science 153 (3742): 1351-1538. DOI: $10.1126 /$ science.153.3742.1351.

Pan G., Dutta H.M. 1998. The inhibition of brain acetylcholinesterease activity of juvenile largemouth bass Micropterus salmoides by sulethal concentrations of diazinon. Environmental Research A 79 (2): 133-137. DOI: 10.1006/enrs.1998.3868.

Przybylska-Wojtyszyn M., Lozińska-Grabska M., Lakota S., Raszka A., Wojtaszek J. 1992. Wpływ deltametryny na narybek karpia. Cz. I. Wpływ subletalnych dawek deltametryny na aktywność aminotransferazy alaninowej i asparaginianowej w narządach wewnętrznych i surowicy karpia (Cyprinus carpio L.) [Effect of deltamethrin on fry of carp. Part. 1. Effect of sublethal doses of deltamethrin on the activity of alanine and aspartate aminotransferases in internal organs and blood serum of carp (Cyprinus carpio L.)] Archiwum Ochrony Środowiska 1: 107-120.

Riege W.H., Cherkin A. 1973. Retroactive facilitation of memory in goldfish by flurothyl. Psychopharmacologia 30 (3): 195-204. DOI: 10.1007/BF00422866.
Scholz N.L., Truelove N.K., French B.L., Berejikian B.A., Quinn T.P., Casillas E., Collier T.K. 2000. Diazinon disrupts antipredator and homing behaviors in chinook salmon (Oncorhynchus tshawytscha). Canadian Journal of Fisheries and Aquatic Sciences 57 (9): 1911-1918. DOI: $10.1139 /$ cjfas-57-9-1911.

Scobie S.R., Bliss D.K. 1974. Ethyl alcohol: relationships to memory for aversive learning in goldfish (Carassius auratus). Journal of Comparative and Physiological Psychology 86 (5): 857-874. DOI: 10.1037/h0036402.

Staatz C.G., Bloom A.S., Lech J.J. 1982. A pharmacological study of pyrethroid neurotoxicity in mice. Pesticide Biochemistry and Physiology 17 (3): 287-292. DOI: 10.1016/0048-3575(82)90139-0.

Sutton M.A., Ide J., Masters S.E., Carew T.J. 2002. Interaction between amount and pattern of training in the induction of intermediate- and long-term memory for sensitization in Aplysia. Learning and Memory 9 (1): 29-40. DOI: $10.1101 / \mathrm{lm} .44802$.

Sutton M.A., Bagnall M.W., Sharma S.K., Shobe J., Carew T.J. 2004. Intermediate-term memory for site-specific sensitization in Aplysia is maintained by persistent activation of protein kinase C. The Journal of Neuroscience 24 (14): 3600-3609. DOI: 10.1523/JNEUROSCI.1134-03.2004.

Svobodová Z., Lusková V., Drastichová J., Svoboda M., Žlábek V. 2003. Effect of deltamethrin on haematological indices of common carp (Cyprinus carpio L.). Acta Veterinaria Brno 72 (?): 79-85.

Szegletes T., Polyhos C.S., Bálint T., Rady A.A., Láng G., Kufcsák O., Nemcsók J. 1995. In vivo effects of deltamethrin on some biochemical parameters of carp (Cyprinus carpio L.). Environmental Monitoring and Assessment 35 (2): 97-111. DOI: 10.1007/BF00633709.

Szerow D., Niemczuk W., Nawrocka E. 1996. Poziom elektrolitów, białka całkowitego i jego frakcji w surowicy oraz skład morfologiczny krwi karpi stawowych z uwzględnieniem wieku i pory roku. [Levels of electrolytes, crude protein, and its fractions in the blood serum and morphological composition of the blood of carp reared in ponds, with consideration of the age and season.] Komunikaty Rybackie 4: 15-18. [In Polish.]

Toovey J.P.G., Lyndon A.R. 2000. Effects of hydrogen peroxide, dichlorvos and cypermethrin on subsequent fecundity of sea lice, Lepeophtheirus salmonis, under fish farm conditions. The European Association of Fish Pathologists 20 (6): 224-228.

Tronel S., Freenstra M.G.P., Sara S.J. 2004. Noradrenergic action in prefrontal cortex in the late stage of memory consolidation. Learning and Memory 11 (?): 453-458. DOI: $10.1101 / \mathrm{lm} .74504$.

Tzschentke T.M. 1998. Measuring reward with the conditioned place preference paradigm: A comprehensive review of drug effects, recent progress and new issues. Progress in Neurobiology 56 (6): 613-672.

Worley P.F., Bhat R.V., Baraban J.M., Erickson C.A., McNaughton B.L., Barnes C.A. 1993. Thresholds for synaptic activation of transcription factors in hippocampus: correlation with long-term enhancement. Journal of Neuroscience 13 (11): 4776-4786. 
Velíšek J., Dobšíková R., Svobodová Z., Modrá H. Lusková V. 2006. Effect of deltamethrin on the biochemical profile of common carp (Cyprinus carpio L.). Bulletin of Environmental Contamination and Toxicology 76 (6): 992-998. DOI: 10.1007/s00128-006-1016-9.

Xia Z., Dudek H., Miranti C.K., Greenberg M.E. 1996. Calcium influx via NMDA receptor induces immediate early gene transcription by a MAP kinase/ERK-dependent mechanism. The Journal of Neuroscience 16 (17): 5425-5436.

Received: 24 April 2009

Accepted: 7 June 2010

Published electronically: 15 December 2010 